\title{
Political Demography of India: Determinants and Consequences
}

\author{
by Parameswara Krishnan \\ Delhi: B.R. Publishing Corporation 2005 \\ ISBN 81-7646-471-6 \\ Hardcover, USD42 (750 INR), xviii + 277 pp.
}

\author{
Reviewed by Frank Trovato \\ Department of Sociology, University of Alberta (Edmonton, Canada) \\ ftrovato@ualberta.ca
}

As the largest democracy in the world, comprising a population of over 1.3 billion people in 2013, India commands the attention of scholars from diverse social scientific disciplines. Professor Krishnan, a prominent scholar of demography and population studies, whose works span subjects from mathematical and statistical demography to sociology, social anthropology, and historical demography, delves in this work into a detailed analysis of the political complexities of India. He applies a variety of statistical methodologies, complemented by the author's own observations and historical research. As described by the author, the main objective of this work is "to introduce the reader to an overview of the political demography of India." Given the complex history of India, its vast territory, large population, and its cultural, linguistic, religious, and socioeconomic diversity, the task undertaken by this author is, to say the least, monumental. This is a remarkable work in its scope, depth, and extensiveness of coverage.

The theoretical framework underlying The Political Demography of India builds on the earlier research of Myner Weiner (i.e., The Sons of the Soil, 1971), from which a series of hypotheses is developed and evaluated empirically with the historical Indian data compiled by Krishnan. Including the introduction, the book contains 14 chapters and six appendixes. The chapters address separate though interrelated aspects of Indian political demography, including: "what is political demography," "the demographic situation in India," "sociodemographic profile of Indian states," "sons of the soil and other socio-political movements," "politics of subjugation and terrorism and its demographic impact," "the political demography of caste in modern India," and "some reflections on the political dimensions of development with special reference to India."

Although it is concluded that India faces significant challenges-due to its relatively slow pace of economic development, uneven modernization across its regions, widespread political corruption, a large and relatively young population in need of productive work and education, and experience of terrorism-Krishnan remains optimistic about the future of his country. Most heartening is the fact that India continues very hard to protect and maintain its parliamentary democratic political system, and that the population generally believes in democratic principles - something which, according to the author, represents an inherent feature of the Indian psyche.

The Political Demography of India is an important work. Students of Indian society, particularly Indian sociopolitical history, as well as those interested in the demography of developing countries, will find this book highly engaging and informative for both teaching and research purposes. 